\title{
DO THE BOARD OF DIRECTORS' CHARACTERISTICS INFLUENCE FIRM'S PERFORMANCE? THE U.S. EVIDENCE
}

\author{
Roman Horváth, Persida Spirollari*
}

\begin{abstract}
:
We examine the relationship of selected Board of Directors' characteristics and firm's financial performance. Using a sample of large U.S firms in 2005-2009, we find that the degree of insider ownership influences positively firm performance, because it reduces agency problems. The age of the Board of Directors matters, to a certain degree, as well. Younger members are probably willing to bear more risk and to undertake major structural changes to improve firm's future prospects. On the other hand, we find that independent directors reduce firm performance and this negative effect was even more important during the recent financial crisis. We suppose that independent directors prefer overly conservative business strategies in order to protect shareholders, but this goes at the cost of lower firm's performance. All in all, our results suggest that corporate governance is important for firm's financial performance.
\end{abstract}

Keywords: corporate governance, firm's performance, board of directors, agency problems, risk, financial crisis.

JEL Classification: G32, G34.

\section{Introduction}

Why are some firms successful, and others not? This question has been for a long time in the interest among economists and already Adam Smith noted that the key to firm's success is to deal with the separation of ownership and control: "The directors of such companies, however, being the managers rather of other people's money than of their own, it cannot well be expected, that they should watch over it with the same anxious vigilance with which the partners in a private co-partnery frequently watch over their own. Negligence and profusion, therefore, must always prevail, more or less in the management of the affairs of such a company." (Smith, reprinted in 2008, p. 700).

To shed light on this issue, we examine empirically the role of corporate governance characteristics on firm's financial performance. While any previous studies focused on the particular aspects of corporate governance, our ambition is to examine the effect of many corporate governance characteristics jointly. More specifically, we consider the effect of the board size, the frequency of Board meetings, insider ownership, average age of Board members, gender diversity and independent directors among corporate

* Roman Horváth, Institute of Economic Studies, Faculty of Social Sciences, Charles University, Prague, Opletalova 26, Praha 1, 11000 (roman.horvath@gmail.com); Persida Spirollari Alpha Bank Albania, Tirana, Albania. R. Horvath acknowledges the support from the Czech Science Foundation Grant No. 402/11/1487. 
governance characteristics. In addition, we use the recent data that cover the period of global financial crisis. This gives us possibility to assess, whether the effect of corporate governance intensifies during the crisis. To do so, we use a sample of U.S. firms traded on S\&P 500 in 2005-2009.

Our results suggest that - controlling for some standard set of financial variables corporate governance characteristics matter for firm's financial performance. More specifically, our results show that the degree of insider ownership influences positively firm's performance, because it reduces agency problems. The age of the Board of Directors matters, to a certain degree, as well. Younger members are probably willing to bear more risk and to undertake major structural changes to improve firm's future prospects. On the other hand, we find that independent directors reduce firm's performance and the reduction was even more important during the recent financial crisis. Our supposition is that independent directors prefer overly conservative business strategies in order to protect shareholders, but this goes at the cost of lower firm's performance.

The paper is organized as follows. Section 2 discusses the related literature. Section 3 provides the data description. An econometric model is presented in Section 4. Section 5 gives the results. Concluding remarks are available in Section 6. Appendix contains some descriptive statistics.

\section{Related Literature}

This section discusses the related literature on how the various corporate governance aspects of the Board of Directors matter for firm's performance. With some level of simplification, we categorize the studies into six main areas: 1) the size of Board of Directors, 2) the Board activity, 3) the Board composition, 4) the insider ownership, 5) the gender diversity and 6) the age of directors.

\subsection{Board size impact on firm's performance}

Prior empirical studies have widely investigated the structure and efficiency of corporate governance systems. Much of the research highlights the crucial role of Board of Directors, considering it as a mechanism enhancing corporate and economic performance. According to Jensen (1993), companies with oversized Boards tend to become less effective. Clearly, a high number of decision-makers in any committee may reduce their effort and give rise to some degree of free-riding. Yermack (1996) addresses these arguments empirically using a sample of U.S. firms and finds that, indeed, having small Boards enhances company's performance and influences positively the investor's behaviour and company value. In addition, the Board size influences the Chief Executive Officer (CEO) compensation incentives as the compensation programs represent an important responsibility of the Board of Directors. Yermack (1996) finds that CEO receives higher compensation incentives in firms with smaller 
Boards. The results also indicate that investors favour a decrease in Board size, and they react negatively in case of Board expansions. Moreover, the changes in Boards of Directors are influenced by the company's performance. For example, companies that perform poorly are characterized by more frequent changes in the Board of Directors, by more departures and more appointments than other good performing companies. However, the research does not support the evidence that companies adjust the Board of Director's size as a result of the past performance.

Interestingly, Adams and Mehran (2008) fail to find a negative effect of the size of Board for the performance of U.S. banks. To the contrary, their results suggest that there is a positive relationship between Board size and Tobin's Q. They argue that this finding reflects the increase in Board size is attributed to more frequent merger and acquisition activity in the U.S. banking industry.

\subsection{The impact of Board of Director's activity on firm's performance}

Another stream of research examines the effect of Board of Director's activity of firm's performance. Vafeas (1999) approximates the intensity of Board activity by the Board meeting frequency (i.e. the number of meetings of Board of Directors each fiscal year). Using a sample of 307 U.S. companies in 1990 - 1994, his results show that firms with a lower number of Board meetings exhibit the highest price to book value. The underlying rationale behind this finding is that too frequent meetings are a signal of less efficient Board members as well as some communication issues among Board members. Vafeas (1999) also shows that there is a positive relationship between the frequency of Board meetings and Board size. This supports the previous finding by Yermack (1996) that suggests higher firm's value for small board sizes.

\subsection{Board composition impact on firm's performance}

This line of research typically focuses on the role that independent directors play for firm performance. The findings are somewhat mixed. Rosenstein and Wyatt (1990) report that the appointment of an additional independent director on Boards composed mostly of independent directors results in an increase in firm's value. This finding supports the idea that independent directors are chosen in accordance with the interest of shareholders. Using a sample of 934 large U.S companies over the period 1985 to 1995, Bhagat and Black (2001) also find that firms react in situations of low profitability by increasing the number of independent directors in the Board.

On the other hand, Peng (2004) investigates whether the appointment of independent directors in a given year is affected by the prior poor performance of the firm and prior firm's size. Using a sample of 530 Chinese firms (traded on stock exchange in China), the results indicate that the effect of Board independence on firm performance is far from robust. Depending on the measure of firm performance, Peng (2004) shows that the effect is either insignificant, or positive. In addition, the effect appears to be much stronger for 
the period 1992-1994 than for 1995-1996. In this regard, Klein (1998) also fails to find a significant relationship between Board committee structure and firm profitability.

Abidin, Kamal and Yusoff (2009) investigate the role of Board structure for firm's performance in Malaysia. Abidin, Kamal and Yusoff (2009) demonstrate the importance of intellectual capital as an important resource which greatly determines the company's performance. The firm's performance is measured as "the value added (VA) efficiency of the firm's physical and intellectual resources" in comparison to previous research using Tobin's Q or other profitability ratios. The VA efficiency is computed by employing the Value Added Intellectual Coefficient (VAIC). The results suggest a positive association between the Board characteristics (measured by the proportion of independent non-executive directors) and the VA efficiency.

\subsection{Insider ownership and firm's performance}

Hayes et al. (2005) explore the interactions between the percentage of shares held by the directors and firm performance. Using a sample of S\&P 500 firms for the period 1997 and 1998, they report a significant positive relationship between the percentage of shares held by independent directors serving on the finance \& investment committee as well as on the strategy committee (but not in the other committees) and firm's performance. A positive relationship is found between the fractions of shares held by CEOs and firm's performance.

\subsection{Gender diversity in the Board and its impact on firm's performance}

Recent research highlights the role of gender diversity for firm's performance (Campbell and Minguez-Vera, 2007). Using data on Spanish Board of Directors, Campbell and Minguez-Vera (2007) find that the percentage of women in the Board of Directors has a significantly positive impact on Tobin's Q value. Adams and Ferreira (2009) also report the positive effect of female directors on firm's outcomes, but this is only so for the regressions not controlling for firm's heterogeneity. Once the firm's heterogeneity is controlled for, the effect becomes insignificant. Interestingly, the Boards with greater gender diversity are found to exhibit lower degree of non-attendance at the Board meetings.

Motivated by the fact that women have been holding an increasing number of Board seats in U.S companies, Dobbin and Jung (2011) analyse whether the presence of female directors in the Board affects company's profit and stock performance. Their results indicate that companies with more women in the Board of Directors do not experience any increase or decrease in profits. On the other hand, the change in the number of female Board members appears to be significant for institutional investors. Institutional investors are found to be more likely to sell their stocks in response to appointments of new female directors. 


\subsection{The average age of directors and firm's performance}

Wiersema and Bantel (1992) focus on the demographic characteristics of the Board and their influence on firm's strategic decisions. The age of Board members represents one of the demographic variables chosen for the study. Using a sample of 100 firms in 1983, they report a negative relationship between the average age of Board members and the changes in corporate strategies. This result shows that younger Boards are more tolerant to bear more risk and are more likely to accept major changes in the process of decision-making in comparison to older directors.

\section{Data}

To examine the effect of corporate governance characteristics on firm's performance, we use the sample of randomly selected 136 firms from S\&P 500 index in 2005-2009. This is comparable sample size to many papers in this stream of literature. For example, Vafeas (1999) uses data for 307 U.S. companies in 1990-1994, Hayes, Mehran and Schaefer (2005) analyse 509 U.S. firms in 1997-1998 and Wiersema and Bantel (1992) has data for 100 U.S. firms in 1983.

Corporate governance of these companies is adopted in accordance with their Corporate Governance Guidelines and Charters of the Board Committee. The Charters of the Board Committee provide the framework of the leadership structure. Most of these companies have four main committees for: compensation, audit, finance, and nominating and governance, which present an integral part of the governance structure. Each of the committee reports and recommends any possible change in relation with the matters for which they are responsible.

The S\&P 500 index companies operate in various industries, such as health care, materials, utilities, energy, information technology, telecommunications services, consumer discretionary, consumer staples and financials. For the purposes of our study, the companies offering financial services with the Standard Industrial Classification Codes 6000-6999 are excluded. The underlying rationale is that these firms operate in very different regulatory environment (Hayes et al., 2005).

Under the regulation rules for securities industry in the U.S, investors and other participants in capital markets should have access to market information before they carry out their investment decisions. For this purpose, public companies are required by the U.S. Securities and Exchange Commission to release accurate financial and non-financial information. Public companies submit periodical reports to the Commission. Most of these reports and other forms have to be filed electronically through EDGAR database (the Electronic Data Gathering, Analysis, and Retrieval System).

For the purpose of our research, we examine the DEF 14A Form, which contains useful information about the proxy statement, published by the companies prior to 
their annual meeting. The proxy statement is filed in accordance with the solicitation of proxies by the company's Board of Directors. For this reason, the company furnishes the shareholders with proxy materials and other information that describe the issues to be discussed upon at the meeting.

Additionally, DEF 14A Form provides detailed information about the governance of the company. The framework of corporate governance is built based on the company's corporate governance guidelines in combination with Board Committee Charters. The Committee Charters give information about the roles and responsibilities of Board of Directors, Compensation Committee, Audit Committee, Finance Committee and Nominating and Governance Committee. Moreover, each of these committees assists the Board in fulfilling its functions by providing specific annual reports with respect to their roles.

Having the information provided in DEF 14A forms, filed by each company of S\&P500 index on a yearly basis, we create a database consisting of the number of directors in the Board, the number of Board meeting during the fiscal year, the proportion of shares owned by the directors and executives as a group, the proportion of insiders and independent directors, the average age of directors and the gender diversity in the Board. The definitions for all governance variables used in this study are given in Table 1 .

Table 1

The Definitions of Corporate Governance Variables

\begin{tabular}{|l|l|}
\hline Board of Directors Size & $\begin{array}{l}\text { The total number of members in the Board of Directors (inclusive } \\
\text { independent directors) attending the annual meetings held during } \\
\text { each fiscal year. }\end{array}$ \\
\hline $\begin{array}{l}\text { Board of Directors } \\
\text { Meetings }\end{array}$ & $\begin{array}{l}\text { The number of regular meetings held by the Board of Directors during } \\
\text { each fiscal year. The meetings refer only to those held in person, } \\
\text { excluding the telephonic meetings. }\end{array}$ \\
\hline Insider Ownership & $\begin{array}{l}\text { The percentage of common stock, relative to the common stock } \\
\text { outstanding, beneficially owned by all directors and executive officers } \\
\text { as a group. }\end{array}$ \\
\hline Average Age & $\begin{array}{l}\text { The average age of board of director's members. } \\
\text { Women in the Board }\end{array}$ \\
$\begin{array}{l}\text { The proportion of women in the Board of Directors, alternatively } \\
\text { the number of women and the dummy variable for the presence of } \\
\text { women in the Board. }\end{array}$ \\
\hline Insider Directors & $\begin{array}{l}\text { Insiders are the directors that participate in the day to day running of } \\
\text { the company. They work full-time in the company and are responsible } \\
\text { for the achievement of operational and strategic objectives. For } \\
\text { example, the CEO represents an inside director. }\end{array}$ \\
\hline Independent Directors & $\begin{array}{l}\text { Independent directors represent the category of directors that are not } \\
\text { employed in the company and do not have any material relationship } \\
\text { with it. These directors are in the role of monitors of the Boards. They } \\
\text { are also called outsiders or external directors. Board independence } \\
\text { is measured by the proportion of independent directors to the Board } \\
\text { size. }\end{array}$ \\
\hline
\end{tabular}


The above definitions about the independence of directors have to be complemented also by the definition relating to corporate governance, given by NYSE and National Association of Securities Dealers (NASD). More specifically, according to NASD and NYSE Rulemaking, it is specified that a director of the Board or of the Audit Committee from is disqualified from being independent when:

1) $\mathrm{He} / \mathrm{She}$ is an employee, or whose immediate family member is an executive officer, of the company.

2) He/She receives, or whose immediate family member receives, more than $\$ 100,000$ per year in direct compensation from the listed company, except for certain permitted payments.

3) He/She is affiliated with or employed by, or whose immediate family member is affiliated with or employed in a professional capacity by, a present or former internal or external auditor of the company.

4) He/She is employed, or whose immediate family member is employed, as an executive officer of another company where any of the listed company's present executives serve on that company's compensation committee.

5) $\mathrm{He} / \mathrm{She}$ is an executive officer or an employee, or whose immediate family member is an executive officer of a company that makes payments to, or receives payments from, the listed company for property or services in an amount which, in any single fiscal year, exceeds the greater of $\$ 1$ million or $2 \%$ of such other company ${ }^{6} \mathrm{~s}$ consolidated gross revenues.

The definitions of financial variables are presented in Table 2. The source of these data is Reuters.

Table 2

The Definitions of Financial Variables

\begin{tabular}{|l|l|}
\hline Price to Book ratio & Price Value per share / Book Value per share \\
\hline Leverage ratio & Total Debt / Total Assets \\
\hline Firm's size & Total Sales / Total Assets \\
\hline
\end{tabular}

\section{Empirical Methodology}

This section discusses our econometric approach. The following equation is estimated:

$$
\begin{aligned}
& Y_{i, t}=a_{0} * \text { BoardSize }_{i, t-1}+a_{1} * \text { BoardActivity }_{i, t-1}+a_{2} * \text { InsiderOwnership }_{i, t-1}+ \\
& a_{3} * \text { Age }_{i, t-1}+a_{4} * \text { Woman }_{i, t-1}+a_{5} * \text { IndependentDirectors }_{i, t-1}+a_{6} * \text { Leverage }_{i, t-1}+ \\
& a_{7} * \text { FirmSize }_{i, t-1}+e_{i, t}
\end{aligned}
$$


Equation (1) represents our baseline equation, where we examine the effect of corporate governance characteristics - controlling for some standard set of financial variables - on $Y_{i, t}$, which denotes the price to book ratio. Specifically, we collect the data for the following corporate governance characteristics: BoardSize $e_{i, t-1}-$ the size of Board of Directors, BoardActivity ${ }_{i, t-1}$ - the number of Board meetings during the year, InsiderOwnership it,-1 $_{1}$ - the number of insider directors, Ag $_{i, t-1}$ - the average age of board directors, Woman $_{i, t-1}$ - the fraction of women in the Board, + IndependentDirectors ${ }_{i, t-1}$ the number of independent directors, Leverage $_{i, t-1}-$ the debt to assets ratio, FirmSize $e_{i, t-1}$ - the sales to assets ratio. $i$ represents the firm and $t$ denotes time. $e_{i, t}$ denotes the residual (which contains random or fixed effects). In some regressions, we also include time dummies to control for unobservable characteristics over time. The Appendix provides some basic descriptive statistics and correlations among variables.

In line with previous literature as briefly summarized in the previous section, we expect that the effect of BoardSize ${ }_{i, t-1}$, BoardActivity ${ }_{i, t-1}$, and Age $_{i, t-1}$, is likely to be negative and the effect of Insider $_{i, t-1}$, and Independent ${ }_{i, t-1}$, and Woman W $_{i, t-1}$ to be positive.

All explanatory variables are lagged by one period to address the endogeneity. The alternative is to employ some dynamic panel data methods such as Arrelano-Bond or Blundell-Bond. Nevertheless, for the dynamic panel data methods greater time coverage would be preferable and therefore, we stick to the fixed effects estimator with lagged explanatory variables.

We estimate several regression models to shed light on the robustness of results. The regressions differ in the way how we control for firm's financial characteristics, year dummies and the definition of Woman $_{i, t-1}$ (our baseline is that we take the fraction of women in the Board, but alternatively also check whether the number of women and simple dummy variable for women makes a difference).

In addition, we also carry out regressions to assess, whether the corporate governance characteristics become more important during the financial crisis. The underlying hypothesis is that the degree of information asymmetry increases during the crisis and corporate governance indicators might play a greater role during the crisis, as they are more reliable in comparison to accounting data. In consequence, market participants may give greater weight in their investment decisions to these characteristics. We assess it as follows. We form two dummy variables Crisis int-1 $_{2}$ and Nocrisis $_{i, t-1}$. The former takes the value of one in the years 2005, 2006 and 2007, zero otherwise. To the contrary, the latter takes the value of zero in the years 2005, 2006 and 2007, one otherwise. Any variable, for example InsiderOwnership ${ }_{i, t-1}$, can be decomposed into two parts Crisis ${ }_{i, t-1}{ }^{*}$ InsiderOwnership ${ }_{i, t-1}$ and Nocrisis ${ }_{i, t-1}$ *InsiderOwnership $_{i, t-1}$. It is easy to show that InsiderOwnership I,t-1 $=$ Crisis $_{i, t-1}{ }^{*}$ InsiderOwnership $_{i, t-1}+$

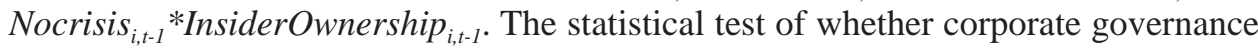
influences the firm performance more during the crisis is then comparing the equality of the corresponding coefficients for Crisis * $_{i,-1}$ InsiderOwnership $_{i, t-1}$ and Nocrisis $_{i, t-1}{ }^{*}$ InsiderOwnership $p_{i, t-1}$. 


\section{Results}

This section provides the results. First, we briefly discuss some descriptive statistics and second, we provide the regression results on whether (and how) corporate governance indicators matter for firm performance.

\subsection{Descriptive statistics}

The descriptive statistics are provided in the Appendix. The statistics are given for each year separately as well as averaged for all five years. In our sample, the Board of Directors holds on average 7.6 meetings per fiscal year with a standard deviation of 3 meetings. The minimum number of meetings in the sample is 3 and the maximum is 28. Throughout the 5-year period, the frequency of Board meetings has remained largely unchanged. Only in year 2007, board activity was somewhat higher reflecting probably the outset of global financial crisis.

On average, there are 11 directors that serve on the Board with a standard deviation of 2 directors. The minimum size of the Board is 5 members and the maximum is 18 . In most firms, the number of elected directors should be within a range stated in advance by the shareholders. As for the frequency of Board meeting, it can be observed that this number remained quite stable from 2005 to 2009.

The independent directors form about $85 \%$ of members on the Board; this implies that the Boards are predominated by outside directors. There are about 9 independent directors on average with a standard deviation of 2 directors. The minimum number of independent directors in the Board is 4 and the maximum is 8 . A small percentage of members in the Board are insiders. There are on average 2 insiders on each Board with standard deviation of 1 inside member. Some Boards are composed only of independent directors and no insiders. During the period 2005-2009, the number of independent directors has remained almost unchanged.

The percentage of insider ownership has remained largely constant from 2005 to 2009 with a mean of $7.6 \%$ and standard deviation $13 \%$. There is a high difference between the minimum, which is 0 and the maximum of $85.4 \%$. This implies that Board directors and executives as a group in some firms may own more than $50 \%$ of the stocks in the firm attributing them the majority of the ownership.

Most Boards are dominated by men and on average, the number of women on Board does not exceed 2. The respective standard deviation is 1. There are many Boards with no female directors. The maximum number of woman in the Board is 6 . Women do not have majority in any firm. There is only one firm in 2009 that has $50 \%$ of women on the Board.

The average age of Board members stand at 60 years with a standard deviation of 3 years. Most of directors are part of the Board for long periods of 10 to 15 years. As a result, having the same directors in the Board implies a constant average age during the 5-year period. The youngest member is 48 years old and the oldest one is 70 . 
The price to book value exhibits substantial variation during the sample period. The mean value of this ratio is 4.2 with the standard deviation of 4.9. In addition, it varies from very low negative numbers to very high positive ones. The minimum value of price to book ratio is -17.27 and the maximum is 79.44 . The negative price to book ratio is an indication that the respective firm has a negative shareholder's equity.

\subsection{Regression results}

This sub-section gives the results on the determinants of firm performance. For all regressions, we carried out Hausman test to choose between random and fixed effects model. We rejected the null hypothesis and therefore opted for fixed effect estimator instead of random effects estimator. The baseline results are available in Table 3 . Table 4 presents additional results, where we try to investigate, whether the effect of corporate governance on firm performance becomes stronger during the recent global financial crisis.

In contrast to Vafeas (1999), our results suggest that neither BoardActivity ${ }_{i, t-1}$, nor BoardSize $_{i, t-1}$ have a significant effect on firm's performance. Our findings rather point to an importance of insider ownership and independent directors for determining price to book ratio. In line with Mehran (1995) or Hayes et al. (2005), the effect of insider ownership is positive. Clearly, insider ownership gives solid incentive mechanism to increase the share prices.

On the other hand, the effect of independent directors is negative on firm's performance. In light of the results of previous literature, this might be somewhat surprising. It is often argued that independent directors improve corporate governance (Rosenstein and Wyatt, 1990, Abidin, Kamal and Yusoff, 2009), which translates into better financial performance. However, the recent theoretical article by Kumar and Sivaramakrishnan (2008) rationalizes, why the presence of independent directors may have an opposite effect on firm performance than typically believed. Kumar and Sivaramakrishnan (2008) show that as directors become less dependent on the CEO (internal directors), the monitoring efficiency of independent directors may decrease and in turn, yield worse financial performance. Alternatively, independent directors may favour excessively conservative business strategies in the belief that they protect shareholders.

The results also give some support that the higher age of Board directors influence negatively the firm performance. Nevertheless, once we control for the time effects the age of Board of Directors keeps its negative sign, but it is no longer statistically significant. The result that younger executives have a positive impact on firm performance is typically attributed to their willingness to bear more risk as well as to undertake major structural changes.

The measures for gender diversity are never found statistically significant. This result is robust to changing the definition of gender diversity. First, we used the fraction of women in the Board (columns 1-3 in Table 3), then the number of women (column 4) 
and finally, the dummy variable for women (column 5). This complies with Adams and Ferreira (2009), which - one controlling for firm's heterogeneity - also fail to find a systematic effect of gender diversity on firm's performance.

Table 3

Does Corporate Governance Characteristics Influence Firm Performance?

\begin{tabular}{|c|c|c|c|c|c|}
\hline & (1) & $(2)$ & (3) & (4) & (5) \\
\hline BoardActivity $_{i, t-1}$ & $\begin{array}{l}-0.046 \\
(0.054) \\
\end{array}$ & $\begin{array}{l}-0.061 \\
(0.056) \\
\end{array}$ & $\begin{array}{l}-0.049 \\
(0.056) \\
\end{array}$ & $\begin{array}{l}-0.049 \\
(0.056) \\
\end{array}$ & $\begin{array}{l}-0.049 \\
(0.056) \\
\end{array}$ \\
\hline BoardSize $_{i, t-1}$ & $\begin{array}{l}-0.15 \\
(0.26)\end{array}$ & $\begin{array}{l}-0.149 \\
(0.257)\end{array}$ & $\begin{array}{l}-0.118 \\
(0.272)\end{array}$ & $\begin{array}{l}-0.212 \\
(0.315)\end{array}$ & $\begin{array}{l}-0.212 \\
(0.315)\end{array}$ \\
\hline InsiderOwnership $_{i, t-1}$ & $\begin{array}{c}0.101^{* * *} \\
(0.038)\end{array}$ & $\begin{array}{l}0.096^{* *} \\
(0.040)\end{array}$ & $\begin{array}{l}0.071^{*} \\
(0.040)\end{array}$ & $\begin{array}{l}0.069^{*} \\
(0.039)\end{array}$ & $\begin{array}{l}0.069^{*} \\
(0.039)\end{array}$ \\
\hline $\boldsymbol{A g e}_{i, t-1}$ & $\begin{array}{c}-0.230^{* *} \\
(0.111)\end{array}$ & $\begin{array}{c}-0.243^{* *} \\
(0.115)\end{array}$ & $\begin{array}{l}-0.144 \\
(0.091) \\
\end{array}$ & $\begin{array}{l}-0.147 \\
(0.092) \\
\end{array}$ & $\begin{array}{l}-0.147 \\
(0.092)\end{array}$ \\
\hline IndependentDirector $_{i, t-1}$ & $\begin{array}{c}-0.540^{* * *} \\
(0.172)\end{array}$ & $\begin{array}{c}-0.544^{* * *} \\
(0.167)\end{array}$ & $\begin{array}{c}-0.410^{* * *} \\
(0.154)\end{array}$ & $\begin{array}{c}-0.414^{* * *} \\
(0.156)\end{array}$ & $\begin{array}{c}-0.414^{* * *} \\
(0.156)\end{array}$ \\
\hline Woman $_{i, t-1}$ & $\begin{array}{l}6.665 \\
(5.34) \\
\end{array}$ & $\begin{array}{c}6.138 \\
(5.4) \\
\end{array}$ & $\begin{array}{c}8.221 \\
(5.209) \\
\end{array}$ & $\begin{array}{c}0.714 \\
(0.496) \\
\end{array}$ & $\begin{array}{c}0.714 \\
(0.496)\end{array}$ \\
\hline FirmSize $_{i, t-1}$ & & $\begin{array}{c}-1.22 \\
(0.885)\end{array}$ & $\begin{array}{l}-0.803 \\
(0.817) \\
\end{array}$ & $\begin{array}{l}-0.813 \\
(0.819) \\
\end{array}$ & $\begin{array}{l}-0.813 \\
(0.819)\end{array}$ \\
\hline Leverage $_{i, t-1}$ & & $\begin{array}{c}1.918 \\
(2.916)\end{array}$ & $\begin{array}{c}4.770 \\
(3.138)\end{array}$ & $\begin{array}{c}4.819 \\
(3.172)\end{array}$ & $\begin{array}{c}4.819 \\
(3.172)\end{array}$ \\
\hline Constant & $\begin{array}{c}22.93^{* * *} \\
(7.49)\end{array}$ & $\begin{array}{c}24.45^{\star \star *} \\
(7.81) \\
\end{array}$ & $\begin{array}{c}14.07^{\star *} \\
(6.08)\end{array}$ & $\begin{array}{c}15.32^{\star *} \\
(6.48)\end{array}$ & $\begin{array}{c}15.32^{\star *} \\
(6.48)\end{array}$ \\
\hline Time effects & No & No & Yes & Yes & Yes \\
\hline Observations & 544 & 544 & 544 & 544 & 544 \\
\hline R-squared & 0.069 & 0.073 & 0.116 & 0.114 & 0.114 \\
\hline Number of firms & 136 & 136 & 136 & 136 & 136 \\
\hline
\end{tabular}

Notes: Fixed effect estimation. All explanatory variables lagged by one period. Woman $_{i, t-1}$ defined as the fraction of women in the Board in columns 1-3, as the number of women in the Board in column 4 and as the dummy variable with the value of 1 , if the number of women in the Board is positive, 0 otherwise. Robust standard errors in parentheses. *** $p<0.01,{ }^{* *} p<0.05,{ }^{*} p<0.1$.

Next, we examine whether the corporate governance indicators, which are found to be significant in Table 3, become more important for firm performance during the recent financial crisis. As explained in Section 4, we decompose the corporate governance indicator, for example, the insider ownership (InsiderOwnership $p_{i, t-1}$ ) into two

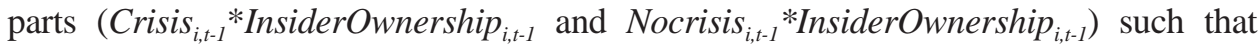
InsiderOwnership $_{i, t-1}=$ Crisi $_{i, t-1} *$ InsiderOwnership ${ }_{i, t-1}+$ Nocrisi $_{i, t-1} *$ InsiderOwnership $p_{i,-1-1}$, which we use as explanatory variables. This decomposition is common in time series 
econometrics, for example, for the threshold autoregressive models. The comparison of the estimated coefficient for these two newly formed explanatory variables serves as assessment, whether the corporate governance indicators are more important during the crisis.

Table 4

Does Corporate Governance Matter More during Financial Crisis?

\begin{tabular}{|c|c|c|c|c|}
\hline & (1) & (2) & (3) & (4) \\
\hline BoardActivity $_{i, t-1}$ & $\begin{array}{l}-0.046 \\
(0.054)\end{array}$ & $\begin{array}{c}-0.062 \\
(0.056)\end{array}$ & $\begin{array}{l}-0.050 \\
(0.054)\end{array}$ & $\begin{array}{l}-0.074 \\
(0.057)\end{array}$ \\
\hline BoardSize $_{i, t-1}$ & $\begin{array}{l}-0.16 \\
(0.26) \\
\end{array}$ & $\begin{array}{l}-0.16 \\
(0.25) \\
\end{array}$ & $\begin{array}{l}-0.183 \\
(0.270) \\
\end{array}$ & $\begin{array}{l}-0.195 \\
(0.266)\end{array}$ \\
\hline InsiderOwnership $p_{i, t-1}$ & & & $\begin{array}{l}0.096^{* *} \\
(0.040)\end{array}$ & $\begin{array}{l}0.087^{* *} \\
(0.040)\end{array}$ \\
\hline NoCrisis ${ }^{\star}$ InsiderOwnership $p_{i, t-1}$ & $\begin{array}{c}0.103^{* * *} \\
(0.039)\end{array}$ & $\begin{array}{c}0.098^{* * *} \\
(0.039)\end{array}$ & & \\
\hline Crisis $^{\star}$ InsiderOwnership $p_{i,-1}$ & $\begin{array}{l}0.087^{* *} \\
(0.037)\end{array}$ & $\begin{array}{l}0.080^{* *} \\
(0.039)\end{array}$ & & \\
\hline $\boldsymbol{A g e}_{i, t-1}$ & $\begin{array}{c}-0.220^{\star *} \\
(0.108)\end{array}$ & $\begin{array}{c}-0.232^{* *} \\
(0.110)\end{array}$ & $\begin{array}{l}-0.180^{*} \\
(0.106)\end{array}$ & $\begin{array}{l}-0.192^{*} \\
(0.105)\end{array}$ \\
\hline IndependentDirector $r_{i, t-1}$ & $\begin{array}{c}-0.527^{\star \star \star} \\
(0.169)\end{array}$ & $\begin{array}{c}-0.528^{\star * *} \\
(0.163)\end{array}$ & & \\
\hline NoCrisis $^{*}$ IndependentDirector ${ }_{i, t-1}$ & & & $\begin{array}{c}-0.440^{\star * *} \\
(0.163)\end{array}$ & $\begin{array}{c}-0.417^{* * *} \\
(0.144)\end{array}$ \\
\hline Crisis $^{\star}$ IndependentDirector ${ }_{i, t-1}$ & & & $\begin{array}{c}-0.513^{\star * *} \\
(0.168)\end{array}$ & $\begin{array}{c}-0.502^{* * *} \\
(0.154)\end{array}$ \\
\hline Woman $_{i, t-1}$ & $\begin{array}{c}6.62 \\
(5.32) \\
\end{array}$ & $\begin{array}{c}6.04 \\
(5.37) \\
\end{array}$ & $\begin{array}{c}7.16 \\
(5.45) \\
\end{array}$ & $\begin{array}{c}6.53 \\
(5.44) \\
\end{array}$ \\
\hline FirmSize $_{i, t-1}$ & & $\begin{array}{l}-1.25 \\
(0.89) \\
\end{array}$ & & $\begin{array}{l}-0.86 \\
(0.83) \\
\end{array}$ \\
\hline Leverage $_{i, t-1}$ & & $\begin{array}{c}2.12 \\
(2.97) \\
\end{array}$ & & $\begin{array}{c}3.62 \\
(2.98) \\
\end{array}$ \\
\hline Constant & $\begin{array}{c}22.32^{* * *} \\
(7.29)\end{array}$ & $\begin{array}{c}23.78^{* * *} \\
(7.57)\end{array}$ & $\begin{array}{c}19.50^{\star * *} \\
(6.81)\end{array}$ & $\begin{array}{c}19.70^{\star * *} \\
(6.68)\end{array}$ \\
\hline Time effects & No & No & No & No \\
\hline Parameter test equality & 2.49 & 2.54 & $5.30 * *$ & $6.73^{* *}$ \\
\hline Observations & 544 & 544 & 544 & 544 \\
\hline R-squared & 0.073 & 0.075 & 0.079 & 0.086 \\
\hline Number of firms & 136 & 136 & 136 & 136 \\
\hline
\end{tabular}

Notes: Fixed effect estimation. All explanatory variables lagged by one period. Woman $_{i, t-1}$ defined as the fraction of women in the Board in columns 1-3, as the number of women in the Board in column 4 and as the dummy variable with the value of 1 , if the number of women in the Board is positive, 0 otherwise. Robust standard errors in parentheses. ${ }^{\star * *} p<0.01,{ }^{* *} p<0.05,{ }^{*} p<0.1$. 
The results are presented in Table 4. We decompose two indicators, InsiderOwnership ${ }_{i, t-1}$ and IndependentDirector ${ }_{i, t-1}$, and examine its effects in columns 1-2 for the former and in columns 3-4 for the latter. In case of InsiderOwnership $p_{i, t-1}$, the estimated coefficient is greater during the crisis period ( 0.103 vs. 0.087 in column 1 and 0.098 vs. 0.080 in column 2), but the test on the equality of parameters do not reject the null hypothesis, i.e. the coefficients do not differ statistically significantly. On the other hand, the effect of IndependentDirector $r_{i, t-1}$ is found to be greater during the crisis, as the parameter equality test rejects the null hypothesis. This suggests that not only the independent directors reduce firm's performance, but the reduction is even more important during the recent financial crisis.

\section{Concluding Remarks}

We examine whether the Board of Directors characteristics influence firm's financial performance. We use the price to book value as a proxy of firm's performance and Board size, independence, insider ownership, gender diversity and the average age of directors as corporate governance indicators. Controlling for a standard set of financial variables, the effect of corporate governance indicators is evaluated using a sample of 136 large S\&P firms in 2005-2009.

The results show that the insider ownership is important for firm's performance. According to our results, insider ownership represents powerful incentive mechanism and limits the issues related to information asymmetry between managers and owners. We also find that the age of the Board of Directors is likely to be associated with firm performance. This is in line with literature, which stressed that younger Board members are less reluctant to undertake structural changes and are generally willing to bear more risk. Interestingly, our results suggest that the independent directors worsen firm performance. This is especially so during the crisis. The explanation for this phenomenon has been put forward by Kumar and Sivaramakrishnan (2008), who show that monitoring efficiency of independent directors may decrease, as they become less dependent on chief executive officers. It is also possible that independent directors prefer business strategies that are too conservative. Gender diversity, proxied by proportion of women on Board appears to be insignificant. Similarly, we fail to find any effect of the frequency of Board meetings and the Board size on firm performance.

Overall, our results show the importance of governance indicators for firm's performance and give several insights on how firms can improve their Board effectiveness and performance. 


\section{Descriptive Statistics}

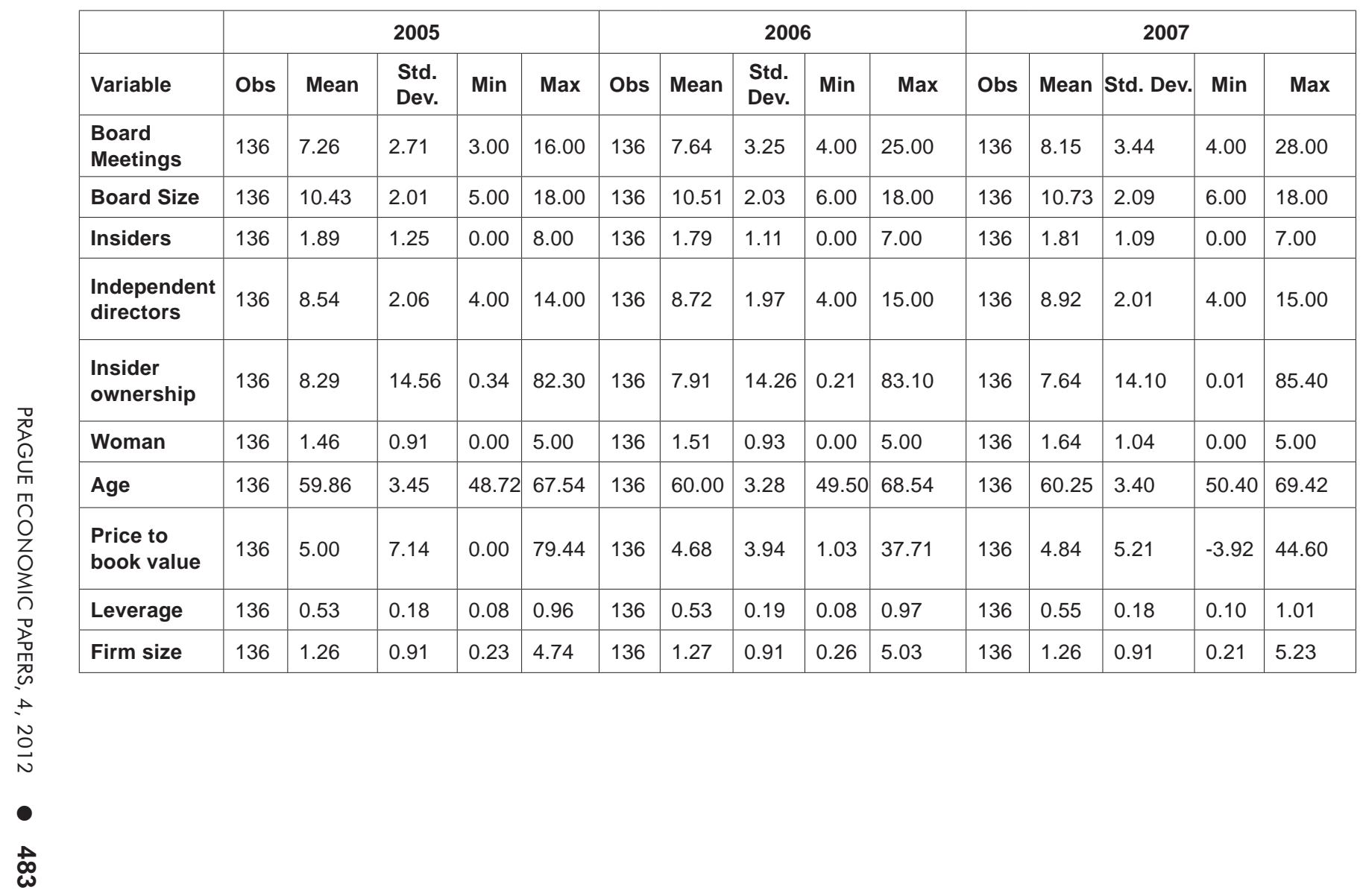


Descriptive Statistics - Continuation

\begin{tabular}{|c|c|c|c|c|c|c|c|c|c|c|c|c|c|c|c|}
\hline \multirow[b]{2}{*}{ Variable } & \multicolumn{5}{|c|}{2008} & \multicolumn{5}{|c|}{2009} & \multicolumn{5}{|c|}{ Average: $2005-2009$} \\
\hline & Obs & Mean & $\begin{array}{l}\text { Std. } \\
\text { Dev. }\end{array}$ & Min & Max & Obs & Mean & $\begin{array}{l}\text { Std. } \\
\text { Dev. }\end{array}$ & Min & Max & Obs & Mean & $\begin{array}{l}\text { Std. } \\
\text { Dev. }\end{array}$ & Min & Max \\
\hline $\begin{array}{l}\text { Board } \\
\text { Meetings }\end{array}$ & 136 & 7.64 & 2.51 & 4.00 & 16.00 & 136 & 7.64 & 3.10 & 4.00 & 22.00 & 680 & 7.66 & 3.02 & 3.00 & 28.00 \\
\hline Board Size & 136 & 10.71 & 1.94 & 6.00 & 17.00 & 136 & 10.56 & 1.94 & 6.00 & 16.00 & 680 & 10.59 & 2.00 & 5.00 & 18.00 \\
\hline Insiders & 136 & 1.68 & 1.11 & 0.00 & 7.00 & 136 & 1.60 & 1.06 & 0.00 & 6.00 & 680 & 1.75 & 1.13 & 0.00 & 8.00 \\
\hline \begin{tabular}{|l|}
$\begin{array}{l}\text { Independent } \\
\text { directors }\end{array}$ \\
\end{tabular} & 136 & 9.03 & 1.96 & 4.00 & 13.00 & 136 & 8.96 & 1.95 & 4.00 & 14.00 & 680 & 8.83 & 2.00 & 4.00 & 15.00 \\
\hline \begin{tabular}{|l} 
Insider \\
ownership
\end{tabular} & 136 & 7.43 & 14.00 & 0.00 & 83.70 & 136 & 6.72 & 12.23 & 0.04 & 70.86 & 680 & 7.60 & 13.82 & 0.00 & 85.40 \\
\hline Woman & 136 & 1.61 & 1.06 & 0.00 & 5.00 & 136 & 1.65 & 1.06 & 0.00 & 6.00 & 680 & 1.57 & 1.00 & 0.00 & 6.00 \\
\hline Age & 136 & 60.65 & 3.19 & 51.40 & 69.00 & 136 & 61.01 & 3.42 & 51.67 & 69.72 & 680 & 60.35 & 3.37 & 48.72 & 69.72 \\
\hline $\begin{array}{l}\text { Price to book } \\
\text { value }\end{array}$ & 136 & 3.50 & 4.02 & 0.59 & 37.82 & 136 & 3.38 & 2.97 & -17.27 & 13.16 & 680 & 4.28 & 4.91 & -17.27 & 79.44 \\
\hline Leverage & 136 & 0.57 & 0.20 & 0.11 & 0.98 & 136 & 0.55 & 0.19 & 0.11 & 1.08 & 680 & 0.54 & 0.19 & 0.08 & 1.08 \\
\hline Firm size & 136 & 1.28 & 0.96 & 0.28 & 5.72 & 136 & 1.16 & 0.91 & 0.17 & 5.56 & 680 & 1.25 & 0.92 & 0.17 & 5.72 \\
\hline
\end{tabular}


Correlation Coefficients of Board Characteristics and Firm's Performance

\begin{tabular}{|c|c|c|c|c|c|c|c|c|c|}
\hline & $\begin{array}{c}\text { Price to } \\
\text { book value }\end{array}$ & $\begin{array}{c}\text { Board } \\
\text { meetings }\end{array}$ & Board size & $\begin{array}{l}\text { Insider } \\
\text { ownership }\end{array}$ & Age & $\begin{array}{l}\text { Independent } \\
\text { directors }\end{array}$ & Gender & $\begin{array}{l}\text { Firm } \\
\text { size }\end{array}$ & Leverage \\
\hline $\begin{array}{l}\text { Price to book } \\
\text { value }\end{array}$ & 1.0000 & & & & & & & & \\
\hline $\begin{array}{l}\text { Board } \\
\text { meetings }\end{array}$ & -0.0009 & 1.0000 & & & & & & & \\
\hline Board size & -0.0938 & -0.0244 & 1.0000 & & & & & & \\
\hline $\begin{array}{l}\text { Insider } \\
\text { ownership }\end{array}$ & 0.0869 & -0.1352 & 0.0292 & 1.0000 & & & & & \\
\hline Age & -0.1768 & 0.0884 & 0.0788 & -0.3170 & 1.0000 & & & & \\
\hline $\begin{array}{l}\text { Independent } \\
\text { directors }\end{array}$ & 0.0278 & 0.0694 & 0.0651 & -0.3430 & 0.1940 & 1.0000 & & & \\
\hline Gender & 0.1350 & 0.0942 & 0.1846 & 0.1500 & -0.1935 & 0.0316 & 1.0000 & & \\
\hline Firm size & 0.0641 & -0.1580 & 0.0472 & 0.0942 & -0.0918 & -0.0345 & 0.1015 & 1.0000 & \\
\hline Leverage & 0.2201 & 0.0679 & 0.1256 & -0.1119 & 0.0900 & 0.1631 & 0.1958 & 0.1276 & 1.0000 \\
\hline
\end{tabular}




\section{References}

Abidin, Z. Z., Kamal, N. M., Jusoff, K. (2009), "Board Structure and Corporate Performance in Malaysia." International Journal of Economics and Finance, Vol. 1, No. 1, pp. 150-164.

Adams, R., Ferreira, D. (2009), "Women in the Boardroom and their Impact on Governance and Performance." Journal of Financial Economics, Vol. 94, No. 2, pp. 291-309.

Adams, R., Mehran, H. (2008), "Corporate Performance, Board Structure, and their Determinants in the Banking Industry." Federal Reserve Bank of New York Staff Reports No. 330.

Bhagat, S., Black, B. (2001), "The Non-Correlation between Board Independence and Long Term Firm Performance." Journal of Corporation Law, Vol. 27, No. 2, pp. 231-274.

Campbell, K., Minguez-Vera, A. (2007), "Gender Diversity in the Boardroom and Firm Financial Performance." Journal of Business Ethics, Vol.83, No. 3, pp. 435-451.

Dobbin, F., Jung, J. (2011), "Corporate Board Gender Diversity and Stock Performance: The Competence Gap or Institutional Investor Bias?" North Carolina Law Review, Vol. 89, No. 3, pp. 809-838.

Hayes, R., Mehran, H., Schaefer, S. (2005), "Board Committee Structures, Ownership, and Firm Performance." Federal Reserve Bank of New York, unpublished.

Jensen, M. (1993), "The Modern Industrial Revolution, Exit, and the Failure of Internal Control Systems." The Journal of Finance, Vol. 48, No. 3, pp. 831-880.

Klein, A. (1998), "Firm Performance and Board Committee Structure." Journal of Law and Economics, Vol. 41, No. 1, pp. 275-303.

Kumar, P., Sivaramakrishnan, K. (2008), "Who Monitors the Monitor? The Effect of Board Independence on Executive Compensation and Firm Value." Review of Financial Studies, Vol. 21, No. 3, pp. 1371-1401.

Mehran, H. (1995), "Executive Compensation Structure, Ownership, and Firm Performance." Journal of Financial Economics, Vol. 38, No. 2, pp. 163-184.

Peng, M. (2004), "Outside Directors and Firm Performance during Institutional Transitions." Strategic Management Journal, Vol. 25, No. 5, pp. 453-471.

Rosenstein, S., Wyatt, J. G. (1990), "Outside Directors, Board Independence and Shareholder Wealth." Journal of Financial Economics, Vol. 26, No. 2, pp.175-191.

Smith, A. (2008), An Inquiry into the Nature and Causes of the Wealth of Nations. New Delhi: Atlantic Publishers and Distributors.

Vafeas, N. (1999), "Board Meeting Frequency and Firm Performance." Journal of Financial Economics, Vol. 53, No. 1, pp. 113-142.

Wiersema, M. F., Bantel, K. A. (1992), "Top Management Team Demography and Corporate Strategic Change." The Academy of Management Journal, Vol. 35, No. 1, pp. 91-121.

Yermack, D. (1996), "Higher Market Valuation of Companies with a Small Board of Directors." Journal of Financial Economics, Vol. 40, No. 2, pp. 185-211. 